\title{
INFLUENCES OF THE 28-YEAR APPLICATION OF FERTILIZER AND MANURE ON SOIL ORGANIC CARBON FRACTIONS IN A MAIZE-WHEAT ROTATION FIELD IN SOUTHERN CHINA
}

\author{
ZHANG, L. M. ${ }^{1,2}-$ LOU, Y. L. ${ }^{3 *}-$ XU, M. G. ${ }^{4}-$ WANG, X. L. ${ }^{5}$ \\ ${ }^{1}$ Research Center of Karst Ecological Environment, The Key laboratory of Plant Resource \\ Conservation and Germplasm Innovation in Mountainous Region (Ministry of \\ Education)/Collaborative Innovation Center for Mountain Ecology \& Agro-Bioengineering, \\ College of Life Sciences/Institute of Agro-Bioengineering, Guizhou University, Guiyang \\ 550025, Guizhou Province, China \\ (e-mail: zhanglimin563406@163.com) \\ ${ }^{2}$ Institute of Guizhou Mountain Resources, Guizhou Academy of Sciences, Guiyang 550001, \\ Guizhou Province, China \\ ${ }^{3}$ Institute of Environment and Sustainable Development in Agriculture, Chinese Academy of \\ Agricultural Sciences, 100081 Beijing, China \\ ${ }^{4}$ Institute of Agricultural Resources and Regional Planning, Chinese Academy of Agricultural \\ Sciences, 100081 Beijing, China \\ (e-mail:mgxu@caas.ac.cn) \\ ${ }^{5}$ College of Agriculture, Guizhou University, Guiyang 550025, Guizhou Province, China \\ (e-mail: ls.wangxl@gzu.edu.cn) \\ *Corresponding author \\ e-mail: louyilai@caas.cn \\ (Received 26 $6^{\text {th }}$ Sep 2021; accepted $23^{\text {rd }}$ Nov 2021)
}

\begin{abstract}
Soil organic carbon (SOC) is an important indicator of soil quality and crop production. In order to optimize management practices and balance agronomic and environmental interests, we conducted physicochemical fractionation to determine the effect of different fertilization treatments on a maize-wheat field in southern China. The fertilization treatments include unfertilized control (CK), nitrogen fertilizer alone (N), balanced fertilizer (NPK) and application of fertilizer plus manure (NPKM). SOC in CK was $6.5 \mathrm{~g} \mathrm{~kg}^{-1}$ lower than that in the NPKM treatment and $1.4 \mathrm{~g} \mathrm{~kg}^{-1}$ higher than that in the N treatment. The proportions of $\mathrm{C}$ fractions to SOC in unprotected pool, physically protected pool and stably protected pool (chemically protected pool plus biochemically protected pool) were $22.2 \sim 43.9 \%$, $4.8 \sim 6.9 \%$, and $49.4 \sim 71.6 \%$, respectively. Soil organic carbon was mainly contained in the unprotected C pool. In addition, the biochemically protected $\mathrm{C}$ showed changing saturation levels in different fertilization treatments. Therefore, the application of fertilizer plus manure might be the best option in order to improve soil TOC and $\mathrm{C}$ fractions in the maize-wheat cropping system.
\end{abstract}

Keywords: different carbon fraction, long-term fertilization, physicochemical fractionation, climate change, southern China

\section{Introduction}

Soil organic carbon (SOC) plays a key role in nutrient supply, improvement of soil physical properties, and erosion control (Stevenson, 1994; Di et al., 2018). SOC is also the source and sink of atmospheric $\mathrm{CO}_{2}$ and it is important for global carbon $(\mathrm{C})$ cycling (Lou et al., 2011; Sun et al., 2021). Therefore, a satisfactory level of SOC is crucial for 
ensuring food security and mitigating climate warming. SOC is a heterogeneous and dynamic substance that varies in $\mathrm{C}$ and $\mathrm{N}$ contents, molecular structure, decomposition rate, and turnover time (Oades, 1988). Soil total organic carbon (TOC) is not able to respond rapidly to soil changes in terrestrial ecosystems, such as fertilization, tillage, and land use. Thus, it is important to classify TOC into different carbon pools according to their decomposition rates or controlling factors, such as water-soluble organic $\mathrm{C}$ (Xu et al., 2011), microbial biomass $\mathrm{C}$ (Wu et al., 2005), and $\mathrm{KMnO}_{4}$-oxidizable $\mathrm{C}$ (Blair et al., 1995). These $\mathrm{C}$ fractions are more sensitive to the changes in soil management practices than soil TOC. TOC was classified into free particulate organic C, intramicroaggregate particulate organic $\mathrm{C}$, and mineral- associated organic $\mathrm{C}$ though the stabilization of SOC by Six et al. (2000, 2002). Based on the physical fractionation method by Six et al. (2000, 2002), Stewart et al. (2008, 2009) proposed a physicochemical fractionation procedure and the associated conceptual SOC model and separated the TOC into various conceptual fraction pools according to different protection mechanisms: unprotected $\mathrm{C}$ pool, physically protected $\mathrm{C}$ pool, chemically protected $\mathrm{C}$ pool, and biochemically protected $\mathrm{C}$ pool. These $\mathrm{C}$ pools provide the basis for understanding the effect of SOC with different management measures.

Numerous studied reported that mineral fertilizers and manure application could increase TOC and C fractions in farmland ecosystems (Tong et al., 2014; Tripathi et al., 2014; Ding et al., 2014; Javaid et al., 2021), but Stewart et al. (2008) and Six et al. (2002) found that silt- or clay-sized $\mathrm{C}$ fractions did not respond to manure and might reach $\mathrm{C}$ saturation level. However, unbalanced or balanced fertilization showed no consistent effects on SOC and C fractions. Some studies showed that mineral fertilizer $(\mathrm{N}, \mathrm{NK}, \mathrm{NP}$, and NPK) alone could significantly increase SOC and C fractions ( $\mathrm{Li}$ et al., 2010; Sun et al., 2013). These results were not consistent with those of another longterm experiment in the Loess Plateau of China by Wu et al. (2004), who reported that the $\mathrm{N}$ fertilizer alone led to lower concentrations of TOC and LFC than the control treatment (CK). Zhang et al. (2009) also demonstrated that only applying $\mathrm{N}$ fertilizer might not sequester $\mathrm{C}$ in the red soil of China. The differences among these study results were mainly ascribed to climate factors, topography, soil types, organic fertilizer addition rates, and the initial SOC level.

There are about 56.9 Mha of red soil, which accounts for $6.5 \%$ of the total arable land in China (Xu et al., 2006; Zhang et al., 2009). Double cropping winter wheat (Triticum aestivium L.) and summer maize (Zea mays L.) are the uppermost grains in this agricultural region. The different $\mathrm{C}$ fractions of long-term fertilizers will affect directly the grain yield and productivity in red soil. The effects of manure or mineral fertilizer on carbon concentration was seldom reported. The physicochemical fractionation procedure of SOC was not used to study SOC fractions in red soil. Therefore, the study aims to explore the influences of 28 -year fertilization treatments in this wheat-maize rotation system on TOC concentration and $\mathrm{C}$ fractions of unprotected $\mathrm{C}$ pool, physically protected $\mathrm{C}$ pool, chemically protected $\mathrm{C}$ pool, and biochemically protected C pool.

\section{Materials and methods}

\section{Site descriptions}

The long-term fertilization experiment was carried out at Qiyang Red soil experimental station in Hunan Province of China $\left(26^{\circ} 45^{\prime} \mathrm{N}, 111^{\circ} 52^{\prime} \mathrm{E}\right)$. The 
meteorological parameters in the site are provided as follows: subtropical humid monsoon, average annual sunshine of about $1623 \mathrm{~h}$, mean annual precipitation of $1431 \mathrm{~mm}$, mean annual temperature of $18{ }^{\circ} \mathrm{C}$, and effective accumulated temperature of about $5600{ }^{\circ} \mathrm{C}$ (Zhang et al., 2009).

The experimental site was constructed in 1990 and the red soil was developed from Quaternary red clay (11.63\% sand, $18.44 \%$ silt,74.18\% clay) and classified as Ferralic Cambisol (FAO, 1988). The soil physical and chemical parameters of topsoil $(0 \sim 20 \mathrm{~cm})$ in the initial year (1990) were provided as follows: total organic carbon (TOC) of $8.58 \mathrm{~g}$ $\mathrm{kg}^{-1}$, total $\mathrm{N}$ of $1.07 \mathrm{~g} \mathrm{~kg}^{-1}$, total $\mathrm{P}$ of $0.45 \mathrm{~g} \mathrm{~kg}^{-1}$, total $\mathrm{K}$ of $13.28 \mathrm{~g} \mathrm{~kg}^{-1}$, available $\mathrm{N}$ of $79.00 \mathrm{mg} \mathrm{kg}^{-1}$, available $\mathrm{P}$ of $10.80 \mathrm{mg} \mathrm{kg}^{-1}$, available $\mathrm{K}$ of $122.00 \mathrm{mg} \mathrm{kg}^{-1}$, bulk density of $1.10 \mathrm{~g} \mathrm{~cm}^{-3}$, and $\mathrm{pH} 5.70$ (soil/water 1:1). The field has been continuously cultivated for 28 years under the wheat-maize rotation mode (Tong et al., 2014).

\section{Experimental design and crop management}

Four fertilization treatments were chosen from eleven treatments of this experiment in the study (Table 1). These treatments include unfertilized control (CK), nitrogen fertilizer alone (N), balanced fertilizer (NPK) and application of fertilizer plus manure (NPKM). Annual application designs of inorganic N, P and K fertilizers and pig manure in various fertilization treatments are shown in Table 1 Mineral inorganic nitrogen, phosphorus and potassium fertilizers were respectively urea, calcium superphosphate, and potassium chloride and pure pig manure was applied. This study just considered about the nitrogen content equaled between the treatment with manure and without manure. The ratio of organic to inorganic nitrogen was 7:3. The carbon and nitrogen concentrations in pig manure were $413.2 \mathrm{~g} \mathrm{~kg}^{-1}$ and $1.67 \mathrm{~g} \mathrm{~kg}^{-1}$ (dry base), respectively. Mineral fertilization was applied before sowing each crop (30\% of mineral N, P and K were applied for the wheat crop and $70 \%$ for the maize crop). However, aboveground biomass was removed from the fields in the plots of all fertilization treatments.

Each treatment was replicated three times in a randomized block design. The area of each plot was $196 \mathrm{~m}^{2}(20 \mathrm{~m} \times 9.8 \mathrm{~m})$. In each year, winter wheat (Triticum aestivium L.) hybrid 'Xiangmai 11' was sown in strips on November 10, and harvested in early May of the next year. Summer maize (Zea mays L.) hybrid 'Yedan 13' was sown in holes between two wheat strips in early April and harvested in July of the same year (Tong et al., 2014). No irrigation was applied in both crops, but herbicides and pesticides were applied during the crop growth periods as required. Grains and straws were air-dried, threshed, oven-dried at $60{ }^{\circ} \mathrm{C}$ to a uniform moisture level, and then weighed separately after harvesting.

Table 1. Annual application of inorganic N, $P$ and $K$ fertilizers and pig manure (dry weight) under various fertilization treatments

\begin{tabular}{|c|c|c|c|c|c|c|c|c|}
\hline \multirow[b]{2}{*}{ Treatments } & \multicolumn{4}{|c|}{ Wheat } & \multicolumn{4}{|c|}{ Maize } \\
\hline & $\begin{array}{c}\text { Inorganic N } \\
\left(\mathrm{kg} \mathrm{ha}^{-1}\right)\end{array}$ & $\begin{array}{c}\text { Inorganic P } \\
\left(\mathrm{kg} \mathrm{ha}^{-1}\right)\end{array}$ & $\begin{array}{c}\text { Inorganic K } \\
\left(\mathrm{kg} \mathrm{ha}^{-1}\right)\end{array}$ & $\begin{array}{c}\text { Pig manure } \\
\left(\mathrm{Mg} \mathrm{ha}^{-1}\right)\end{array}$ & $\begin{array}{c}\text { Inorganic N } \\
\left(\mathrm{kg} \mathrm{ha}^{-1}\right)\end{array}$ & $\begin{array}{c}\text { Inorganic P } \\
\left(\mathrm{kg} \mathrm{ha}^{-1}\right)\end{array}$ & \begin{tabular}{|c|} 
Inorganic K \\
$\left(\mathrm{kg} \mathrm{ha}^{-1}\right)$
\end{tabular} & $\begin{array}{c}\text { Pig manure } \\
\left(\mathrm{Mg} \mathrm{ha}^{-1}\right)\end{array}$ \\
\hline $\mathrm{CK}$ & 0 & 0 & 0 & 0 & 0 & 0 & 0 & 0 \\
\hline $\mathrm{N}$ & 90 & 0 & 0 & 0 & 210 & 0 & 0 & 0 \\
\hline NPK & 90 & 16 & 31 & 0 & 210 & 37 & 73 & 0 \\
\hline NPKM & 27 & 16 & 31 & 3.9 & 63 & 37 & 73 & 9.4 \\
\hline
\end{tabular}

anorganic $\mathrm{N}$ fertilizer is urea; $\mathrm{P}$ is Calcium superphosphate; $\mathrm{K}$ is $\mathrm{KCl}$

${ }^{\mathrm{b}}$ In dry weight 


\section{Soil sampling}

Three composite soil samples for each plot was prepared by mixing five soil cores (inner diameter: $5 \mathrm{~cm}$; height: $20 \mathrm{~cm}$ ) collected randomly from the surface soil (0 20 cm) after harvesting summer maize in 2017. Six samples were collected for each treatment. Samples were packaged to maintain the uncompacted state at constant temperature and then brought to the laboratory. Large rocks, obvious litters, and roots were removed after samples were air-dried and then carefully broken by hands and passed through an $8-\mathrm{mm}$ sieve, a $2 \mathrm{~mm}$ sieve and a $0.15 \mathrm{~mm}$ sieve. Soil sample passing through a $2 \mathrm{~mm}$ sieve was subjected to fractionation and soil sample passing through a $0.15 \mathrm{~mm}$ sieve was used to measure total organic carbon. All samples of each treatment were stored at room temperature for further analysis.

\section{Soil fractionation and $C$ analyses}

Three fractionation steps of soil organic carbon were detailed and given by Stewart et al. (2008, 2009). These steps included wet sieving-isolation of microaggregates, density flotation, and acid hydrolysis (Fig. 1). In the first step, $>250 \mu \mathrm{m}$ coarse particulate organic matter (cPOM), 53 250 $\mu \mathrm{m}$ microaggregate $\mathrm{C}$ fractions, and $<53 \mu \mathrm{m}$ silt- and clay-sized C fractions (d-silt and d-clay) were obtained. Soil sample ( $20 \mathrm{~g}$ ) was placed on a $250 \mu \mathrm{m}$ sieve and carefully shaken with 30 glass beads on the top of the microaggregate isolator containing water filling two thirds of the volume of the isolator. After $20 \mathrm{~min}$, the fraction with the size $>250 \mu \mathrm{m}$ and the fraction with the size between $250 \mu \mathrm{m}$ and $53 \mu \mathrm{m}$ fractions were collected in an aluminium specimen box. The fraction with the size $<53 \mu \mathrm{m}$ and water was centrifuged $(127 \times g$ for $7 \mathrm{~min}, 1730 \times g$ for $15 \mathrm{~min}$ ) in a bucket to separate the easily dispersed silt- and clay-sized $\mathrm{C}$ fractions. All fractions were dried at $60^{\circ} \mathrm{C}$, weighed, and stored.

The second step involved further density flotation and dispersion of microaggregate fraction obtained in the first step. This step generated fine particulate organic matter (fPOM), physically protected $\mathrm{C}$ fractions (iPOM) with the size $>53 \mu \mathrm{m}$, and microaggregate-derived silt- and clay-sized $\mathrm{C}$ fractions ( $\mu$-silt and $\mu$-clay) with the size $<53 \mu \mathrm{m}$. Firstly, $50 \mathrm{~mL}$ of $1.70 \mathrm{~g} \mathrm{~cm}^{-3}$ sodium iodide solution was used to initiate density flotation. Then, these samples were centrifuged at $1250 \times \mathrm{g}$ for $20 \mathrm{~min}$ at room temperature, filtered with the filter paper of $0.45 \mu \mathrm{m}$, and then washed with deionized water for five times to remove sodium iodide. The components on the $0.45 \mu \mathrm{m}$ filter paper were fine fraction and this filtrate was collected for reuse. Meanwhile, the heavy fraction left in centrifuge tube was washed five times with deionized water, and then $60 \mathrm{~mL}$ of $5 \mathrm{~g} \mathrm{~L}^{-1}$ sodium hexametaphosphate was added, shaken for $18 \mathrm{~h}$ with 12 glass beads in oscillator, and passed through a $53 \mu \mathrm{m}$ sieve to separate the physically protected $\mathrm{C}$ fractions and silt- and clay-sized $\mathrm{C}$ fractions. The further separation step of silt- and clay-sized $\mathrm{C}$ was the same with that in the first step.

The third step involved acid hydrolysis of the silt- and clay-sized $\mathrm{C}$ fractions (d-silt and d-clay; $\mu$-silt and $\mu$-clay). In the acid hydrolysis step, $6 \mathrm{~mol} \mathrm{~L}^{-1} \mathrm{HCl}$ was added in the sample, which was immersed in water bath at $95{ }^{\circ} \mathrm{C}$ for $16 \mathrm{~h}$. After refluxing, the sample was filtered and washed with deionized water. All residues were collected in an aluminium specimen box, dried at $60{ }^{\circ} \mathrm{C}$, and weighed. Acid hydrolysis fractions included $\mathrm{H}-\mathrm{dsilt}, \mathrm{H}-\mathrm{dclay}, \mathrm{H}-\mu$ silt, and $\mathrm{H}-\mu \mathrm{dsilt}$. Non- hydrolysis fractions including $\mathrm{NH}$-dsilt, $\mathrm{NH}$-dclay, $\mathrm{NH}-\mu$ silt, and $\mathrm{NH}-\mu$ dsilt were obtained by subtracting carbon concentration of acid hydrolysis fractions from total carbon concentration. Carbon 
concentrations in all fractions were measured with an EA 3000 elemental analyzer (Italy) (From Shanghai Wolong Instrument Co., Ltd).

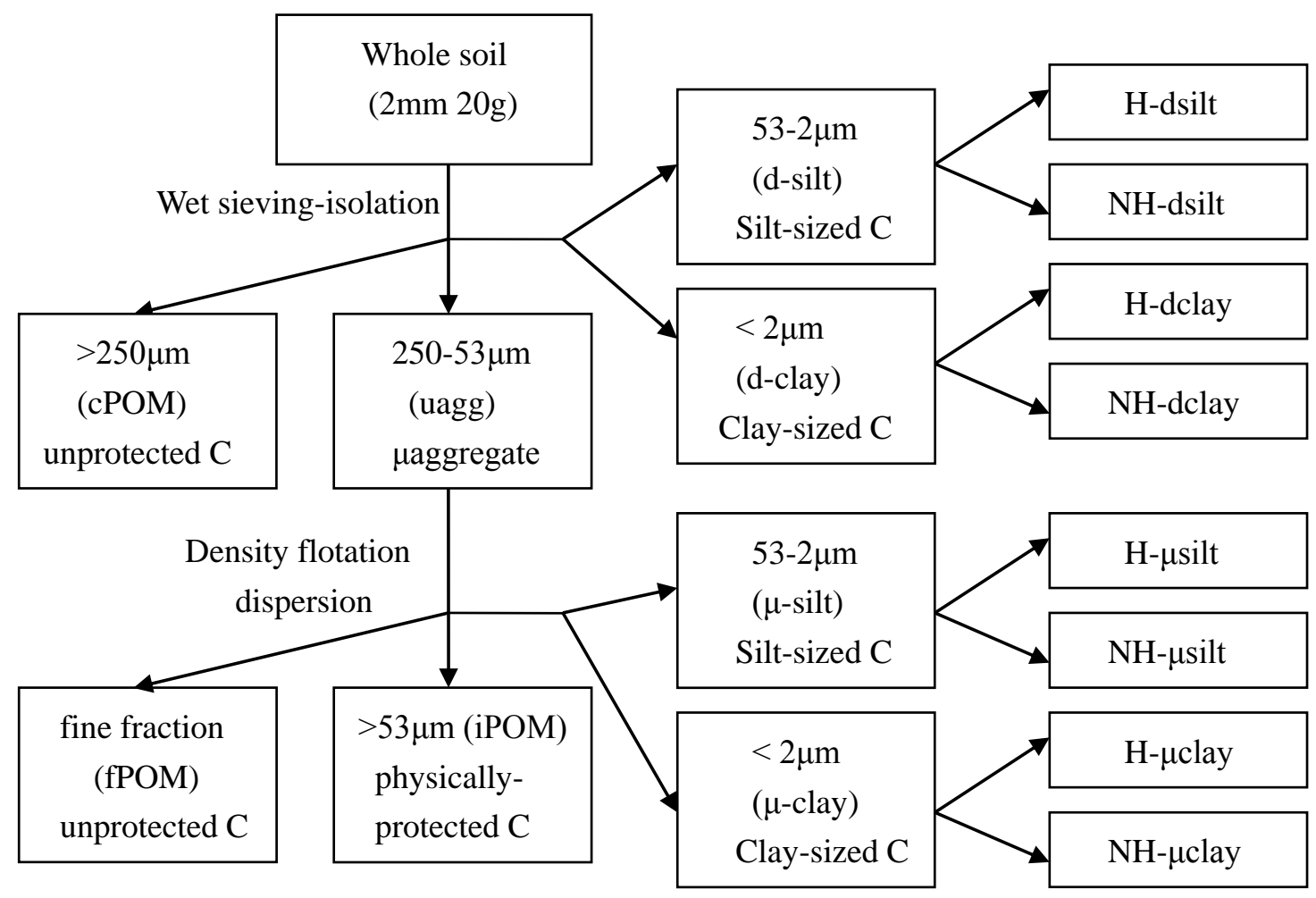

Figure 1. Fractionation procedure of soil organic carbon for different $C$ pools. $c P O M$ and fPOM indicate unprotected C; iPOM indicate physically protected C; $\mathrm{H}$-dsilt, $\mathrm{H}$-dclay, $\mathrm{H}$ - $\mu$ silt, and $\mathrm{H}$ - $\mu$ clay (hydrolysable silt \& clay) indicate chemically protected $\mathrm{C}$; $\mathrm{NH}$-dsilt, $\mathrm{NH}$-dclay,

$\mathrm{NH}-\mu$ silt, and $\mathrm{NH}-\mu \mathrm{clay}$ (non-hydrolysable silt \& clay) indicate biochemically protected $\mathrm{C}$

\section{Data analysis}

Annual grain yield and annual carbon input were calculated with the data from 1990 to 2017. All data were analyzed by SPSS Statistics 17.0. Analysis of variance (ANOVA) was performed with a LSD test to analyze the significant difference among different treatments $(P<0.05)$ was considered to be statistically significant.

\section{Results}

\section{Soil TOC}

Figure 2 shows soil TOC concentrations in different fertilizations treatments. Soil TOC concentrations in different treatments in the 28-year wheat-maize rotation period were decreased according to the following order: NPKM $>$ NPK $>$ CK $>\mathrm{N}$. Obviously, TOC concentration in the soil in the NPKM treatment showed the greatest increase of $13.9 \mathrm{~g} \mathrm{~kg}^{-1}$ and was $4.5 \mathrm{~g} \mathrm{~kg}^{-1}, 7.9 \mathrm{~g} \mathrm{~kg}^{-1}$, and $6.5 \mathrm{~g} \mathrm{~kg}^{-1}$ higher than TOC in the soil in the treatments of NPK, N, and CK. However, TOC concentration in the soil in the $\mathrm{N}$ treatment was the lowest $\left(6.0 \mathrm{~g} \mathrm{~kg}^{-1}\right)$ and $1.4 \mathrm{~g} \mathrm{~kg}^{-1}$ lower than that in the CK treatment. 


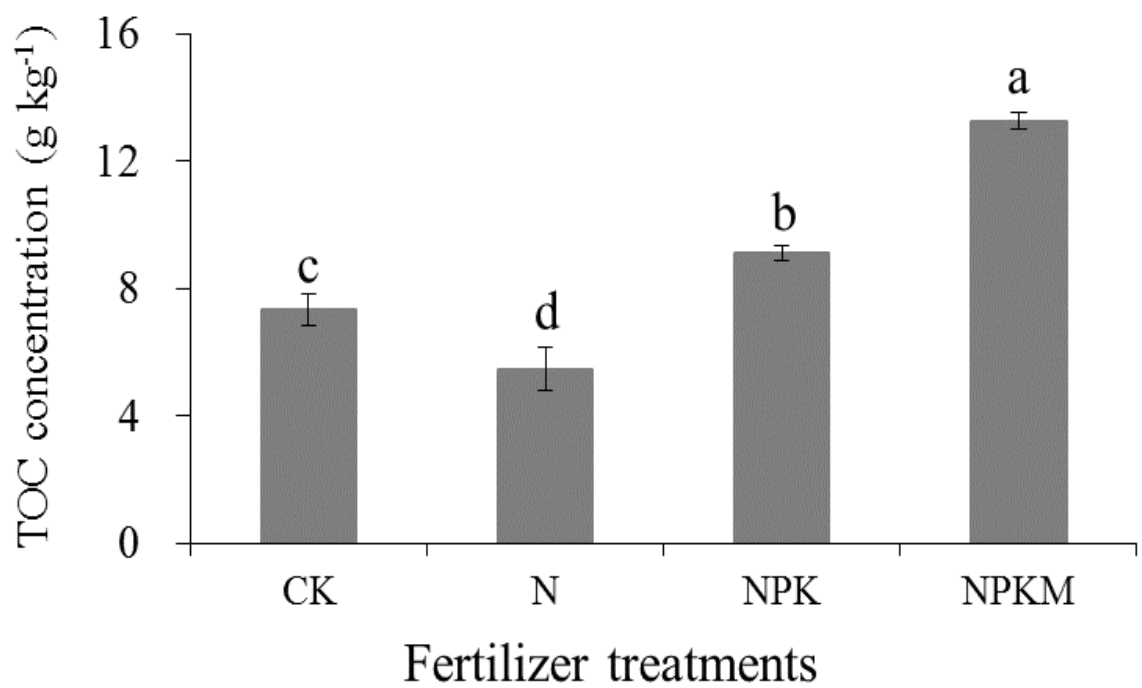

Figure 2. Effects of long-term fertilization on content of soil total organic carbon (TOC). Bars represent mean + standard error. Different lowercase letters indicate significant differences among all treatments $(P<0.05)$

\section{Soil C fractions}

As expected, the application of fertilizer plus manure (NPKM) resulted in significant increases in various carbon fractions except $\mathrm{NH}$-clay (Table 2). In the unprotected $\mathrm{C}$ pool, NPKM treatment had the highest $\mathrm{C}$ concentration in cPOM fraction, which was 1 time, 4 times, and 2 times than that in NPK, N and CK treatments. However, fPOM fraction showed the lowest $\mathrm{C}$ concentration in all $\mathrm{C}$ fractions. Soil $\mathrm{C}$ concentrations in different treatments was decreased according to the following order: $\mathrm{NPKM}>\mathrm{NPK}>\mathrm{N}=\mathrm{CK}$ in iPOM of physically protected $\mathrm{C}$ pool. Soil $\mathrm{C}$ concentration in chemically protected $\mathrm{C}$ pool in NPKM treatment was $1.25 \mathrm{~g} \mathrm{~kg}^{-1}$ higher than that in $\mathrm{CK}$ treatment. In biochemically protected $\mathrm{C}$ pool, all treatments assumed different effects on $\mathrm{C}$ concentration. In biochemically protected $\mathrm{C}$ pool, $\mathrm{C}$ concentration in NPKM treatment was $0.68 \mathrm{~g} \mathrm{~kg}^{-1}$ higher than that in the $\mathrm{CK}$ treatment and $\mathrm{C}$ concentration in $\mathrm{N}$ treatment was $0.62 \mathrm{~g} \mathrm{~kg}^{-1}$ lower than that in the $\mathrm{CK}$ treatment. Furthermore, stable fractions showed the highest $\mathrm{C}$ concentration in all fractions after long-term fertilization treatments.

\section{Soil C fractions in TOC}

In all treatments, the proportion of stable $\mathrm{C}$ fractions (chemically protected plus biochemically protected) to TOC was the highest (Fig. 3). The proportions of various $\mathrm{C}$ fractions to TOC were decreased according to the following order: stable $\mathrm{C}$ fractions (49.4 71.6\%) > unprotected $\mathrm{C}$ fractions $(22.2 \sim 43.9 \%)>$ physically protected $\mathrm{C}$ fractions $(4.8 \sim 6.9 \%)$. Compared with CK, NPKM treatment significantly improved the proportions of unprotected and physically protected $\mathrm{C}$ fractions, but decreased the proportion of stable $\mathrm{C}$ fractions. In the NPK treatment, only physically protected $\mathrm{C}$ fractions was increased significantly. Meanwhile, $\mathrm{N}$ treatment reduced unprotected $\mathrm{C}$ fractions and significantly increased chemically protected $\mathrm{C}$ fractions. However, the proportion of stable $\mathrm{C}$ fractions in the NPKM treatment was the lowest and the highest in the $\mathrm{N}$ treatment. 


$$
-835-
$$

Table 2. Soil organic carbon fractions of different carbon pools under long-term fertilization treatments $\left(\mathrm{g} \mathrm{kg}^{-1} \text { soil }\right)^{\&}$

\begin{tabular}{c|c|c|c|c|c|c|c|c}
\hline \multirow{2}{*}{ Treatments } & \multicolumn{7}{c}{ SOC fractions } \\
\cline { 2 - 8 } & Unprotected & $\begin{array}{c}\text { Physically } \\
\text { protected }\end{array}$ & Chemically protected & \multicolumn{2}{|c}{$\begin{array}{c}\text { Biochemically } \\
\text { protected }\end{array}$} & $\begin{array}{c}\text { Stable } \\
\text { fractions }\end{array}$ \\
\cline { 2 - 9 } & cPOM & fPOM & iPOM $^{\#}$ & H-silt & H-clay & NH-silt & NH-clay & Total $^{\$}$ \\
\hline CK & $2.08 \mathrm{c}$ & $0.27 \mathrm{~b}$ & $0.35 \mathrm{c}$ & $1.76 \mathrm{~b}$ & $0.65 \mathrm{~b}$ & $1.65 \mathrm{~b}$ & $0.56 \mathrm{a}$ & $4.63 \mathrm{bc}$ \\
$\mathrm{N}$ & $1.03 \mathrm{~d}$ & $0.18 \mathrm{~b}$ & $0.34 \mathrm{c}$ & $1.42 \mathrm{~b}$ & $0.90 \mathrm{ab}$ & $1.21 \mathrm{c}$ & $0.37 \mathrm{~b}$ & $3.92 \mathrm{c}$ \\
NPK & $2.69 \mathrm{~b}$ & $0.29 \mathrm{ab}$ & $0.63 \mathrm{~b}$ & $2.17 \mathrm{ab}$ & $0.79 \mathrm{~b}$ & $1.90 \mathrm{~b}$ & $0.64 \mathrm{a}$ & $5.49 \mathrm{~b}$ \\
NPKM & $5.39 \mathrm{a}$ & $0.43 \mathrm{a}$ & $0.88 \mathrm{a}$ & $2.57 \mathrm{a}$ & $1.09 \mathrm{a}$ & $2.29 \mathrm{a}$ & $0.61 \mathrm{a}$ & $6.55 \mathrm{a}$ \\
\hline
\end{tabular}

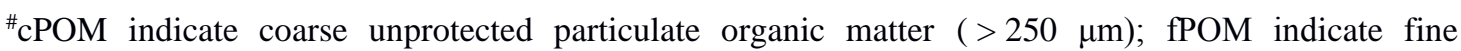
unprotected POM (lighter than $1.70 \mathrm{~g} \mathrm{~cm}^{3}, 53-250 \mu \mathrm{m}$ ); iPOM indicate physically protected POM (heavier than $1.70 \mathrm{~g} \mathrm{~cm}^{3}$, > $53 \mu \mathrm{m}$ ); H-silt indicate hydrolysable silt-sized fraction (acid soluble, 53$2 \mu \mathrm{m}$ ); H-clay indicate hydrolysable clay-sized fraction (acid soluble, $<2 \mu \mathrm{m}$ ); NH-silt indicate nonhydrolysable silt-sized fraction (acid resistant, 53-2 $\mu \mathrm{m}$ ); NH-clay indicate non-hydrolysable clay-sized fraction (acid resistant, $<2 \mu \mathrm{m}$ )

${ }^{\&}$ Different lowercase letters indicate significant differences among all treatments $(\mathrm{P}<0.05)$

\$The sum of H-silt, H-clay, NH-silt and NH-clay

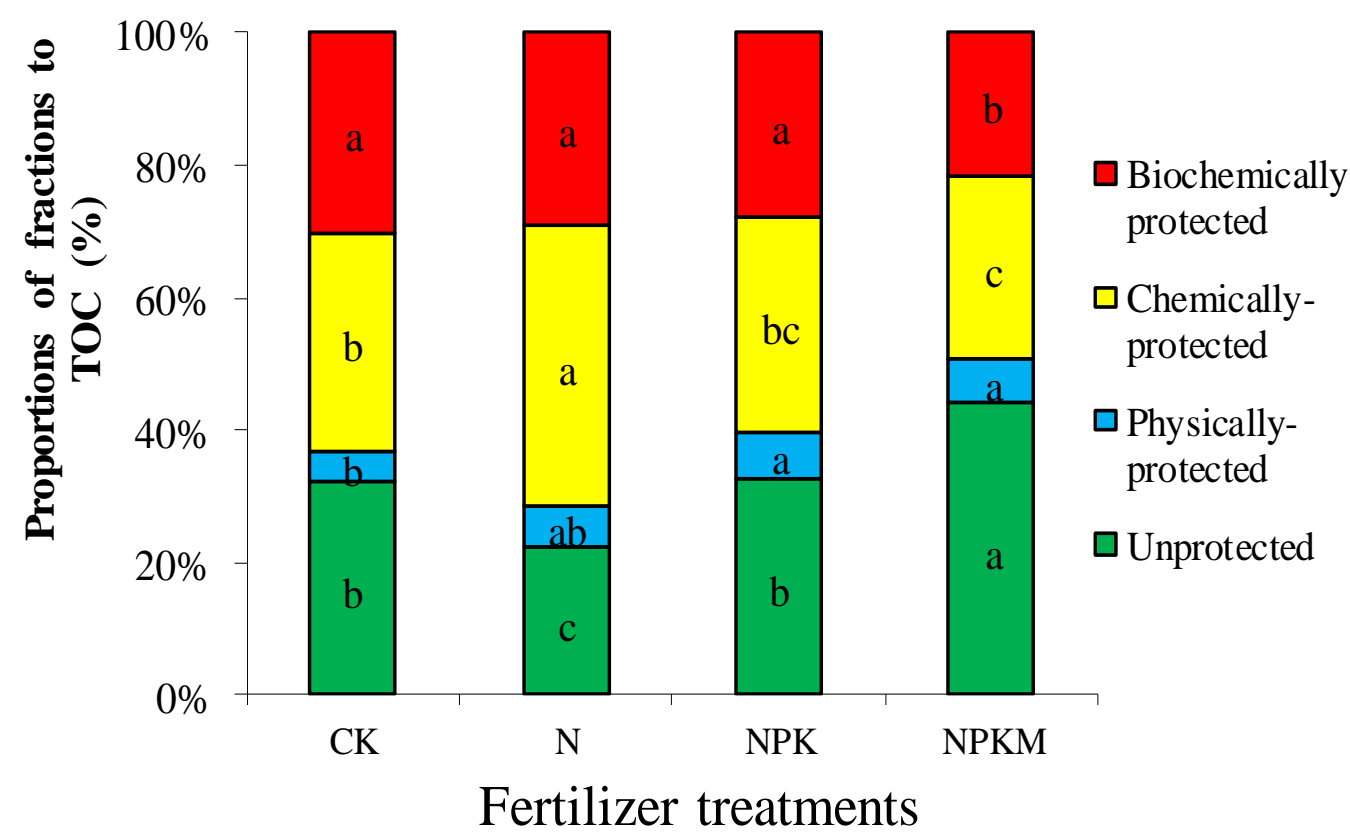

Figure 3. Effects of long-term fertilization on the proportions of soil fractions carbon to total organic carbon. Different lowercase letters indicate significant differences among all treatments $(P<0.05)$

\section{Discussion}

The application of chemical fertilizer and manure increased significantly soil organic carbon concentration (Bhattacharyya et al., 2010; Liang et al., 2014; Di et al., 2018; Che et al., 2021). In our studies, soil TOC was improved by $88 \%$ after the long-term application of mineral fertilizer and manure compared with CK treatment (Fig. 2). Long-term applications of animal manure generally increased TOC in two ways. 
Organic matters contained in applied manure increased TOC and the increased organic matters of crop residues due to the higher crop yields after the application of manure correspondingly increased TOC (Batande et al., 2020). In the plot, mean annual grain yield of wheat and maize in NPKM treatment was the highest (6883 $\left.\mathrm{kg} \mathrm{ha}^{-1} \mathrm{yr}^{-1}\right)$, thus leading to a tremendous carbon input $\left(6.29 \mathrm{t} \mathrm{ha}^{-1} \mathrm{yr}^{-1}\right)$ compared with other treatments (Table 3). The more the carbon input was, the greater the C-saturated degree in TOC of soil was (Six et al., 2002; Stewart et al., 2008; Huo et al., 2018). The effects of fertilizer and manure application on TOC have been realized and utilized for nearly 4000 years in China, Japan, and Korea (Dormaar et al., 1988).

Table 3. Effects of long-term different fertilization treatments to grain yield and carbon input

\begin{tabular}{|c|c|c|c|c|c|c|}
\hline \multirow{3}{*}{ Treatments } & Wheat & Maize & \multirow{3}{*}{ Total } & $\mathbf{C a}$ & nput & \multirow{3}{*}{ Total } \\
\hline & \multicolumn{2}{|c|}{ Annual grain yield } & & Crop & Manure & \\
\hline & \multicolumn{2}{|c|}{$\mathrm{kg} \mathrm{ha}^{-1} \mathrm{yr}^{-1}$} & & \multicolumn{2}{|c|}{ t ha $^{-1} \mathrm{yr}^{-1}$} & \\
\hline CK & 362 & 286 & $648 c$ & 0.24 & 0.00 & $0.24 \mathrm{c}$ \\
\hline $\mathrm{N}$ & 303 & 545 & $848 \mathrm{c}$ & 0.25 & 0.00 & $0.25 \mathrm{c}$ \\
\hline NPK & 1060 & 2876 & $3937 b$ & 0.83 & 0.00 & $0.83 b$ \\
\hline NPKM & 1772 & 5111 & $6883 a$ & 1.50 & 4.79 & $6.29 \mathrm{a}$ \\
\hline
\end{tabular}

Annual grain yield is dry weight. Different lowercase letters indicate significant differences among all treatments $(\mathrm{P}<0.05)$

However, the TOC in the $\mathrm{N}$ treatment was the lowest $\left(6.0 \mathrm{~g} \mathrm{~kg}^{-1}\right)$, which was even lower than that in the CK treatment $\left(7.4 \mathrm{~g} \mathrm{~kg}^{-1}\right)$. No significant difference in carbon input was observed between the $\mathrm{N}$ treatment and $\mathrm{CK}$ treatment, but the lowest $\mathrm{pH}$ (3.77) occurred in 2017 after successive $\mathrm{N}$ fertilizer application (Table 3, Fig. 4). Soil acidification would lead to soil hardening and the decline in soil fertility and may not sequester C (Zhang et al., 2009). Only $\mathrm{N}$ fertilizer may enhance the decomposition of TOC in the soil due to the high temperature and abundant rainfall. The observation was not consistent with the previous reports (Campbell et al., 1991). Wu et al. (2004) found that $\mathrm{N}$ fertilizer stimulated microbial activities and enhanced TOC decomposition and that the MB-C in N fertilizer treatment was 17 110\% higher than in the control. The higher MB-C suggested the higher activities of microorganisms and the more intensive decomposition activities of soil organic carbon ( $\mathrm{Ci}$ et al., 2015; Li et al., 2017).

Effects of fertilization on soil C fractions Kandeler et al. (1999) in Germany and Gerzabek et al. (2001) in central Sweden demonstrated that organic manure could increase in SOC concentration in particle-sized fractions. In this study, NPKM treatment increased significantly each $\mathrm{C}$ fraction, especially cPOM of unprotected pool, which was 2.6 times of that in the CK treatment. Sleutel et al. (2006) also proved that fertilizer and manure application promoted the $\mathrm{C}$ fractions in the unprotected pool. In our experiments, the proportions of $\mathrm{C}$ fractions to TOC in unprotected pool, physically protected pool, and stably protected pool (chemically protected pool plus biochemically protected pool) were respectively 22.2 43.9\%, 4.8 6.9\%, and 49.4 71.6\% (Fig. 3). Stewart et al. (2009) stated that the $\mathrm{C}$ fractions of the unprotected pool (cPOM + fPOM) accounted for 9 46\% of TOC. Köbl and Kögel-Knabner (2004) reported that the C fractions of the physically protected pool (iPOM) accounted for 5.0 9.8\% of TOC in silty clay loam soils. Tong et al. (2014) found that the $\mathrm{C}$ fractions of stable $\mathrm{C}$ pool 


$$
-837 \text { - }
$$

accounted for $45.2 \sim 76.6 \%$ of TOC under different fertilization treatments in red soil in southern China. The results were consistent with previous results (Stewart et al., 2012; Ding et al., 2014).

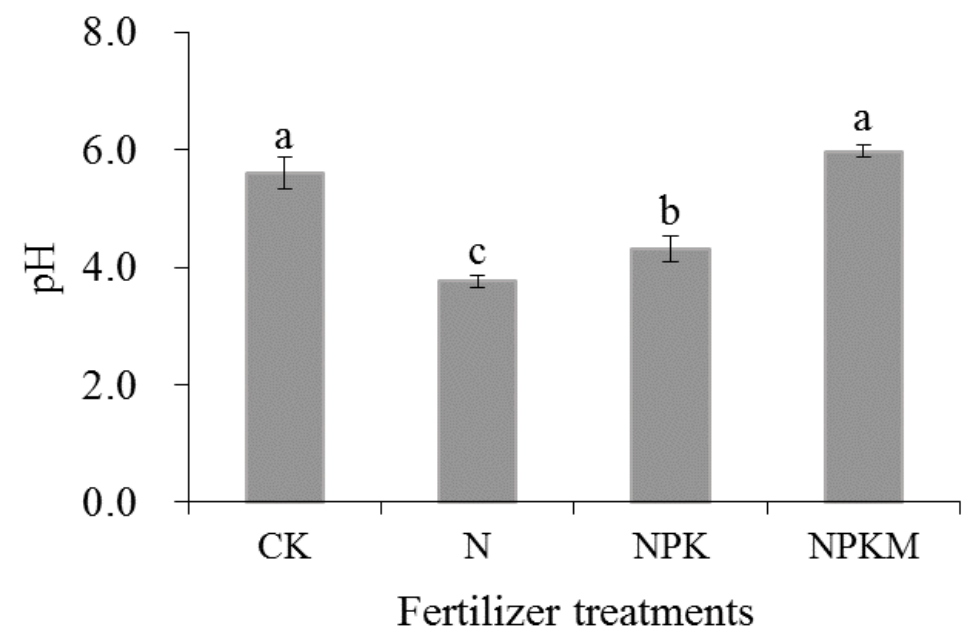

Figure 4. Effects of long-term fertilizer to soil $p H$. Bars represent mean + standard error. Different lowercase letters indicate significant differences among all treatments $(P<0.05)$

The biochemically protected $\mathrm{C}$ pool is acquiring protection through condensation and complexation reactions or the inherent complex biochemical nature of the material (Lu et al., 2021). Biochemically protected $\mathrm{C}$ consisting of the non-hydrolyzable silt and clay particles are old stabilized organic carbon, which is hypothesized to be unaffected by management or interacted with charcoal or other materials. Biochemically protected $\mathrm{C}$ would be expected to reach a saturation level. In this study, the proportion of biochemically protected $\mathrm{C}$ fractions to stable $\mathrm{C}$ fractions showed no significant change among different fertilization treatments except $\mathrm{N}$ treatment. This phenomenon indicated that biochemically protected $\mathrm{C}$ fractions might reach a saturation level. The result was consistent with previous reports (Six et al., 2002; Stewart et al., 2008; Wang et al., 2021). The different result of the $\mathrm{N}$ treatment might be ascribed to the low $\mathrm{pH}$ (3.77) and the high concentration of HCL $\left(6 \mathrm{~mol} \mathrm{~L}^{-1}\right)$, which stimulated the degree of acid hydrolysis. It is necessary to adopt more powerful analytical tools, such as polymerase chain reaction (PCR) technique and ${ }^{13} \mathrm{C}$ NMR spectroscopy to explore the phenomenon of biochemically protected $\mathrm{C}$ fractions in the $\mathrm{N}$ treatment.

\section{Conclusions}

Continuous application of fertilizer plus manure in 28 years significantly increased soil TOC and $\mathrm{C}$ fractions, but the application of $\mathrm{N}$ fertilizer alone showed the inconsistent result with $\mathrm{CK}$ treatment in the wheat-maize rotation system in the red soil in southern China. Soil organic carbon was mainly contained in the unprotected $\mathrm{C}$ pool, indicating that the unprotected $\mathrm{C}$ pool was the more sensitive indicator than soil TOC or other $\mathrm{C}$ fractions. In addition, biochemically protected $\mathrm{C}$ showed the tendency of a saturation level in different fertilization treatments. It is necessary to adopt the polymerase chain reaction (PCR) technique or ${ }^{13} \mathrm{C}$ NMR spectroscopy to further explore the effects of fertilizer and manure application on soil carbon fractions. 
Acknowledgments. Funding was provided by the Project of National Key Research and Development Program of China (grant number 2016YFC0502604); and the Construction Program of Biology Firstclass Discipline in Guizhou (GNYL[2017]009).

Author contributions. L. Z. analyzed the data and wrote the manuscript. L. Z. and X. W. performed the experiments. M. X. provided helpful suggestions in design of the project. Y. L. conceived and designed the project. All authors read and approved the final manuscript.

Conflict of interests. The authors declare no conflict of interests.

\section{REFERENCES}

[1] Batande, S. N., Dou, S., Zhang, X. W. (2020): Corn straw return can increase labile soil organic carbon fractions and improve water-stable aggregates in Haplic Cambisol. Journal of Arid Land 12: 1018-1030.

[2] Bhattacharyya, R., Ved Prakash Kundu, S., Srivastva, A. K., Gupta, H. S. (2010): Long term effects of fertilization on carbon and nitrogen sequestration and aggregate associated carbon and nitrogen in the Indian sub-Himalayas. - Nutrient Cycling Agroecosyst 86: 116.

[3] Blair, G. J., Lefroy, R. D., Lise, L. (1995): Soil carbon fractions based on their degree of oxidation, and the development of a carbon management index for agricultural systems. Australia Journal Agricultural Research 46: 1459-1466.

[4] Campbell, C. A., Biederbeck, V. O., Zentner, R. P., LaFond, G. P. (1991): Effect of crop rotations and cultural practices on soil organic matter, microbial biomass and respiration in a thin Black Chernozem. - Canada Journal Soil Science 71: 363-376.

[5] Che, Q. J., Li, M., Zhang, Z. S. (2021): Effects of biochar application on soil organic carbon in degraded saline-sodic wetlands of Songnen Plain, Northeast China. - Chinese Geographical Science 31: 877-887.

[6] Ci, E., Mahdi, M. A., Wang, L., Ding, C. H., Xie, D. T. (2015): Soil organic carbon mineralization as affected by cyclical temperature fluctuations in a karst region of southwestern China. - Pedosphere 25: 512-523.

[7] Di, J. Y., Xu, M. G., Zhang, W. J., Tong, X. G., He, X. H., Gao, H. J., Liu, H., Wang, B. R. (2018): Combinations of soil properties, carbon inputs and climate control the saturation deficit dynamics of stable soil carbon over 17-year fertilization. - Scientific Reports 8: 1-10.

[8] Ding, X., Yuan, Y., Liang, Y., Li, L., Han, X. (2014): Impact of long-term application of manure, crop residue, and mineral fertilizer on organic carbon pools and crop yields in a Mollisol. - Journal of Soils and Sediments 14: 854-859.

[9] Dormaar, J. F., Lindwall, C. W., Kozub, G. C. (1988): Effectiveness of manure and commercial fertilizer in restoring productivity of an artificially eroded Dark Brown Chernozemic soil under dryland conditions. - Canada Journal Soil Science 68: 669-679.

[10] Gerzabek, M. H., Haberhaue,r G., Kirchman, H. (2001): Soil organic matter pools and carbon-13 natural abundances in article-size fractions of a long-term agricultural field experiment receiving organic amendments. - Soil Science Social American Journal 65: 352-358.

[11] Huo, L. L., Zou, Y. C., Yu, X. G., Zhang, Z. S., Wang, X. H. (2018): Effect of Wetland reclamation on soil organic carbon stability in peat mire soil around Xingkai Lake in Northeast China. - Chinese Geographical Science 28: 325-336.

[12] Javaid, M. D., Lotfollah A. L. (2021): Changes in soil organic carbon, nitrogen and sulphur along a slope gradient in apple orchard soils of Kashmir Himalaya. - Journal of Mountain Science 18: 2377-2387.

[13] Kandeler, E., Stemmer, M., Klimanek, E. M. (1999): Response of soil microbial biomass, urease and xylanase within particle size fractions to long-term soil management. - Soil Biological Biochem 31: 261-273. 
[14] Köbl, A., Kögel-Knabner, I. (2004): Content and composition of free and occluded particulate organic matter in a differently textured arable Cambisol as revealed by solidstate ${ }^{13} \mathrm{C}$ NMR spectroscopy. - Journal Plant Nutrient Soil Science 167: 45-53.

[15] Li, Z., Liu, M., Wu, X., Han, F., Zhang, T. (2010): Effects of long-term chemical fertilization and organic amendments on dynamics of soil organic $\mathrm{C}$ and total $\mathrm{N}$ in paddy soil derived from barren land in subtropical China. - Soil Tillage Research 106: 268-274.

[16] Li, D. J., Xiao, K. C., He, T. G. (2017): Impacts of vegetation restoration strategies on soil organic carbon and nitrogen dynamics in a karst area, southwest China. - Ecological Engineering 101: 247-254.

[17] Liang, Q., Chen, H., Gong, Y., Yang, H., Fan, M., Kuzyakov, Y. (2014): Effects of 15 years of manure and mineral fertilizers on enzyme activities in particle-size fractions in a North China Plain soil. - European Journal of Soil Biology 60: 112-119.

[18] Lou, Y. Y., Wang, J., Liang, W. (2011): Impacts of 22-year organic and inorganic N managements on soil organic $\mathrm{C}$ fractions in a maize field, northeast China. - Catena 87: 386-390.

[19] Lu, X. L., Li, S. S., Liu, J. H., Duan, Y. X., Yue, H., Kang, J. H., Wu, H. L. (2021): Distribution of soil water-stable aggregates and organic carbon content affected by tillage systems: a meta-analysis. - Journal of Drainage and Irrigation Machinery Engineering 39: 1051-1055.

[20] Oades, J. M. (1988): The retention of organic matter in soils. - Biogeochemistry 5: 35-70.

[21] Six, J., Elliot, E. T., Paustian, K. (2000): Soil macroaggregate turnover and microaggregate formation: a mechanism for $\mathrm{C}$ sequestration under no-tillage agriculture. - Soil Biology \& Biochemistry 32: 2099-2103.

[22] Six, J., Conant, R. T., Paul, E. A., Paustian, K. (2002): Stabilization mechanisms of soil organic matter: implications for C-saturation of soils. - Plant and Soil 241: 155-176.

[23] Sleutel, S., De Neve, Németh, T., Tóth, T., Hofman, G. (2006): Effect of manure and fertilizer application on the distribution of organic carbon in different soil fractions in long-term field experiments. - European Journal of Agronomy 25: 280-288.

[24] Stevenson, F. J. (1994): Humus Chemistry: Genesis, Composition, Reaction. - Wiley, New York, pp. 1-24.

[25] Stewart, C. E., Plante, A. F., Paustian, K., Conant, R. T., Six, J. (2008): Soil carbon saturation: linking concept and measurable carbon pools. - Soil Science Society of American Journal 72: 379-392.

[26] Stewart, C. E., Paustian, K., Conant, R. T., Plante, A. F., Six, J. (2009): Soil carbon saturation: Implications for measurable carbon pool dynamics in long-term incubations. Soil Biology and Biochemistry 41: 357-366.

[27] Sun, Y., Huang, S., Yu, X., Zhang, W. (2013): Stability and saturation of soil organic carbon in rice fields: evidence from a long-term fertilization experiment in subtropical China. - Journal Soils Sediments 13: 1327-1334.

[28] Sun, Z. X., Bai, H. Q., Ye, H. C., Zhou, Z. Q., Huang, W. J. (2021): Three-dimensional modelling of soil organic carbon density and carbon sequestration potential estimation in a dryland farming region of China. - Journal of Geographical Sciences 31: 1453-1468.

[29] Tong, X. G., Xu, M. G., Wang, X., Bhattacharyya, R., Zhang, W. J., Cong, R. (2014): Long-term fertilization effects on organic carbon fractions in a red soil of China. - Catena 113: 251-259.

[30] Tripathi, R., Nayak, A. K., Bhattacharyya, P., Shukla, A. K., Shahid, M., Raja, R., Panda, B. B., Mohanty, S., Kumar, A., Thilagam, V. K. (2014): Soil aggregation and distribution of carbon and nitrogen in different fractions after 41 years long-term fertilizer experiment in tropical rice-rice system. - Geoderma 213: 280-286.

[31] Wang, R. J., Song, J. S., Feng, Y. T., Zhou, J. X., Xie, J. Y., Asif, K., Che, Z. X., Zhang, S. L., Yang, X. Y. (2021): Changes in soil organic carbon pools following long-term fertilization under a rain-fed cropping system in the Loess Plateau, China. - Journal of Integrative Agriculture 20: 2512-2525. 


$$
-840-
$$

[32] Wu, T. Y., Schoenau, J. J., Li, F. M., Qian, P. Y., Malhi, S. S., Shi, Y. C., Xue, F. L. (2004): Influence of cultivation and fertilization on total organic carbon and carbon fractions in soils from the Loess Plateau of China. - Soil Tillage Research 77: 59-68.

[33] Wu, T. Y., Schoenau, J. J., Li, F. M., Qian, P. Y., Malhi, S. S., Shi, Y. C. (2005): Influence of fertilization and organic amendments on organic-carbon fractions in Heilu soil on the loess plateau of China. - Journal Plant Nutrient Soil Science 168: 100-107.

[34] Xu, M. G., Liang, G. Q., Zhang, F. D. (2006): Evolution of Soil Fertility in China. Agricultural Science and Technology Press of China, Beijing, pp. 88-90 (in Chinese).

[35] Xu, M. G., Lou, Y. Y., Sun, X., Wang, W. M., Baniyamuddin, K. Z. (2011): Soil organic carbon active fractions as early indicators for total carbon change under straw incorporation. -Biology and Fertility of Soils 47: 745-752.

[36] Zhang, H. M., Wang, B. R., Xu, M. G., Fan, T. L. (2009): Crop yield and soil responses to long-term fertilization on a red soil in southern China. - Pedosphere 19: 199-207. 